\title{
Print Culture and English-Speaking Quebec
}

\section{by Peter F. McNally}

The role of English-speaking Quebecers in the cultural development of both Quebec and Canada generally tends to be overlooked, but in fact is too important to be ignored. This article discusses Anglophone Quebec's contribution to print culture in three time-periods: 1764-1820,1820-1890, and 1890 to the present. However, many important aspects of this culture still require serious investigation or synthesis.

Le rôle des Québécois anglophones dans le développement culturel du Québec et du Canada a généralement tendance à ne pas être pris en considération, alors qu'il est trop important pour être ignoré. Cet article est consacré à la contribution des anglophones du Québec à la culture imprimée à trois époques: 1764-1820, 1820-1890 et 1890 à aujourd'hui. Il a reste toutefois que plusieurs aspects importants de cette culture doivent faire l'objet de recherches ou de synthèses sérieuses.

Anglophone Quebec's contribution to print culture in Quebec and Canada is in danger of falling amor.g competing schools of opinion and, therefore, of becoming invisible. For some commentators, Qeubec's anglophone culture is an irritating anomaly which distracts from the definition of the province as an exclusively French-speaking territory; for others, anglophone Quebec is viewed solely within a broader Canadian anglophone context, devoid of reference to the unique aspects of Quebec heritage; for yet others, anglophone Quebec is best ignored because of the complexity involved in dealing with such a difficult issue. Although these generalizations, like all generalizations, are overstated and admit to important exceptions there is a persistent sense, in some quarters, of anglophone Quebecers having been orphaned among competing solitudes. McTernan's two volume bibliography of French-language Quebec imprints, in the British Library (1992-93), ${ }^{1}$ contributes to this sense. For most commentators, however, the role of English-speaking Quebecers in the cultural development of Quebec specifically, and Canada generally, is too important to be ignored; clearly no history of Canadian print culture can afford to overlook anglophone Quebec.

\section{To 1820}

Anglophone interest in Canada generally, and Quebec specifically, began during the French regime, as the bibliographies of Waldon ${ }^{2}$ and Waterston ${ }^{3}$ make clear. There having been no printing press in New France, only in 1764 - with the beginning of the English regime - was printing introduced into the new province with a dynasty of English-speaking printers who dominated Quebec City's printing for the next 60 years: William Brown and Thomas Gilmore (1764-1773), William Brown (1773-1789), Samuel Neilson (1789-1793), and John Neilson (1793-1822). ${ }^{4}$ Although Canadian printing began in Halifax in 1751, Quebec City with its larger population and economic/political importance soon became the centre of printing in late 18th and early 19 th century Canada. While slightly more than $50 \%$ of the books published in Quebec between 1764 and 1820 were in French, a press having been established in Montreal in 1776, the fact is that only 1,100 or so titles were actually printed. Anglophone titles accounted for $27 \%$ and bilingual English/French titles for $18 \%$.

Recent studies have shown that the bulk of 18th 


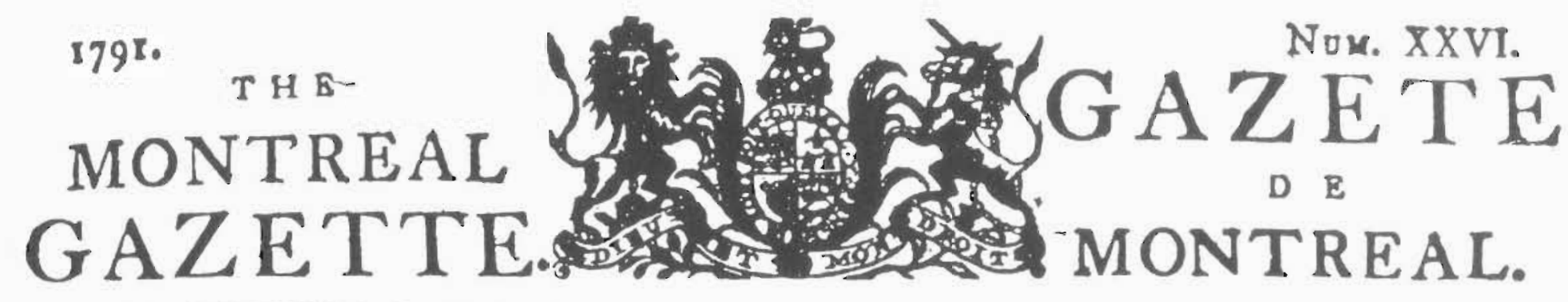

T H. U.R S D A Y, J O * 16.

JEUDI, 16 IU I.

\section{U B L I N,}

Fazeary to.

A CTRCUSSTANCE of a mol dreadful nature hes throfpired ichin thefe few days:-Aright of two ago * a very lart hoos, iwa perfons, feemingly. geotemen, drove themfelves ont in a potichaife to Charchtown? where tbere is a berial places, with a dead body contined up in the carriage. They rapped up ibe graveligger, and told bim, that aoder the difguife of oight they had broaght oot 'or to be interned, whicb in the day tiroe, they upprebended, mighe be arreted for debe, and foe the buriel of which be thould bare a grioes.

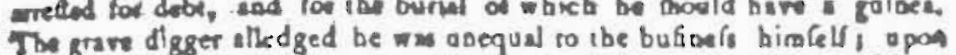
bich thele perloos faid ibey would give bim balf a guidea for an affenots - hich wa agreed $\mathrm{m}_{3}$, and the corplo was accordingly left with ibe gravedever. The later immediately called up 20 effilat i bat apon agreeent they determiaed upon pouponing the bafoefis till day light. Whon thr arofe in the morulog, curiolity arged them 10 open, ibe coffin, whiction fo doing Ul thocking ia bentiond ther found the body of a

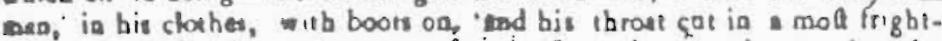
ful manper. In bis porkets were found, fx guiness and a watch; for the penperty of which thefe two perfone differed, or elfe the tranfadion would probably have nerer come to ' $\mathrm{T} g$ ht. The boly remaias at this piace to be ouned, which as yet, has noo iaked piace: wor bar any thing ocorred which ca: lead in a teovery. Every $c 5$ : wiroefs of ibis borrid, fou! rastactiva, is prayin: fot the developecoe.n of the cruel gerpetrator.

\section{O N D O N, Fistustr 10.}

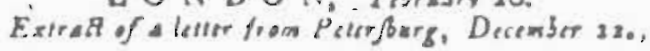

At a Protedant metting in Strofourg, the following prayer is offered Ip ewice a day, foe the natiooal atjerabliv:

"Almighty Gad! animate by thy power the depatict of the Franks! Cherion, in their beates.' in defatigable ieal wich is so deseftary to acselarate the accomplimment of oor welfarol be their quidel be their
D B P A I I, le to Ftrriet.

Sleari da Mond fur.

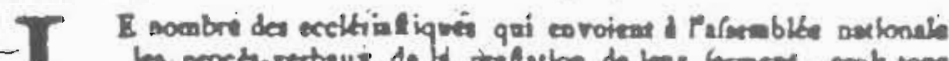

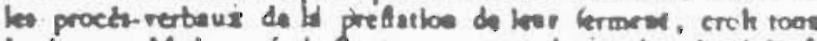

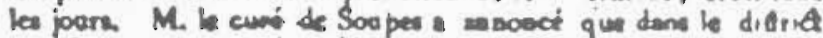

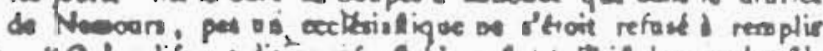

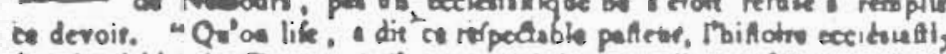

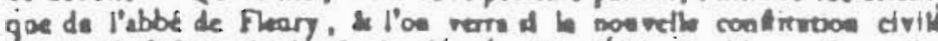

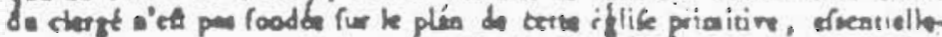

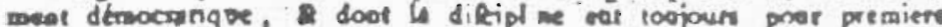

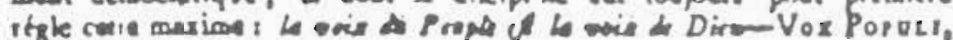
Vox Des.

Ledtpart des Merdimes, tantel do Rol, fiese toeve la capitale en

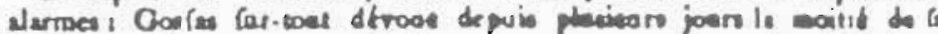

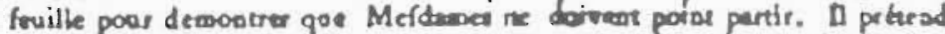

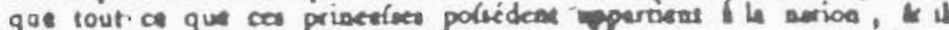

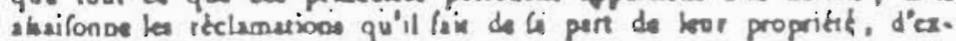
prefsion qui ne foot pas trab bonnties.

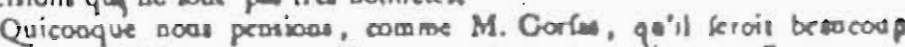

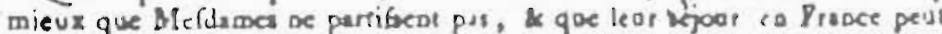

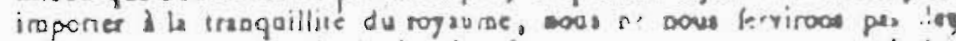

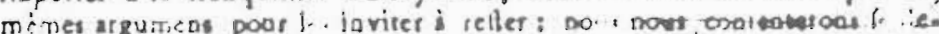

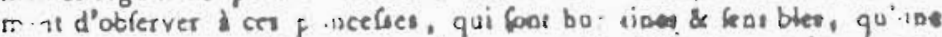

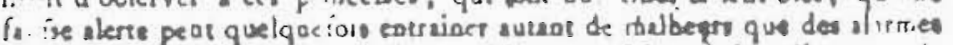

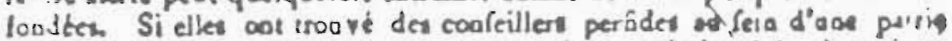

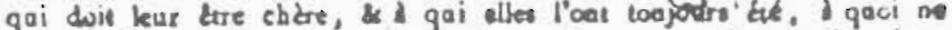
doivens-ilkes pas s'attendre; quad elles as feroor entositeo que de pretres faratiquea \& enoemir d'une contitutior asi a's enjevé aux misifrea de

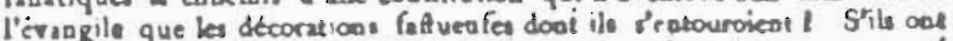

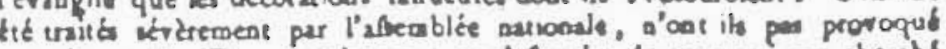
re traitement? Dans tous les cas; ce n'elt point de cour qui oset cherchs

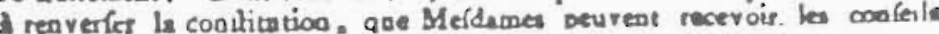


century Canadian printing revolved around newspapers and job printing such as printed forms, handbills, and broadsides. ${ }^{5}$ Of the seven newspapers published in 18th century Quebec, only two endured over time: the Montreal Gazette (initially francophone) and the Quebec Gazette. Both were bilingual publications, at various points in their history, before becoming unilingually English. Of the two magazines published in 1.8th century Canada, one appeared in Quebec, the bilingual Quebec Magazine, 1792-1794. The bulk of handbills and printed forms appeared in English.

Concerning the diffusion of publications in 18th century Quebec, both Montreal. and Quebec City had libraries dating from the French regime, all of which were attached to religious institutions, such as hospitals and colleges, and none of which was designed to be available to the general public. The first to be open to the general public were bilingual subscription libraries, whose collections were more or less evenly divided between English and French language books: the Quebec Library opened by Governor Haldimand in Quebec City in 1779, and the Montreal Library opened in $1796 .{ }^{6}$ There is no evidence of bookstores in 18th century Quebec, except for those attached to printing establishments, and which probably also doubled as lending libraries. Personal libraries of significance emerged at an early date among anglophones.

\section{III. $1820-1890$}

Although John Neilson continued to dominate Quebec City printing well into the 19th century, the focus of Quebec's anglophone publishing after 1820 switched to other parts of the province such as Three Rivers, and the Eastern Townships. ${ }^{7}$ Montreal, which had established itself as the economic and cultural metropolis of British North America, and had an anglophone majority between 1831 and 1865, emerged as the centre for English-language publishing not only in Quebec but all of Canada. This hegemony, which would endure up to 1890 , was based upon both original publishing and unauthorized reprinting of British and American books, for which royalties would not be paid. The chaotic and uncooperative nature of Canadian, British, and
American copyright laws both permitted and encouraged such anarchy.

Montreal's two leading publishers were Dawson Brothers and John Lovell. Lovell was particularly significant, becoming Canada's leading publisher in English and French, as well as developing a significant presence in the United States. Even today the firm continues to enjoy an important role in the publishing of directories and other reference works. Dawsons was particularly active in publishing scholarly works, including the books of Sir John William Dawson, McGill University's great principal and Canada's leading intellectual/scientist of the 19th century. In time the Renouf publishing company would evolve from Dawsons. Although both Dawsons and Lovell indulged in issuing unauthorized editions of British and American works, they also printed authorized editions in co-operation with various foreign authors and publishers. As a reflection of its cultural and economic dynamism, Victorian Montreal became the leading Canadian publisher of English language legal and medical titles. ${ }^{8}$

English language periodical and newspaper publishing in Quebec during this period was particularly important. Montreal newspapers such as the Gazette, Herald, Star and Witness exerted national influence. ${ }^{9}$ Local English language newspapers could be found in Quebec City and other centres across the province. Montreal magazines played an considerable role in the development of an indigenous English Canadian tradition of periodical publishing. The Literary Garland (1838-1851) was the country's first literary journal, in English or French, to enjoy real longevity. Snow Drop (1847-1853) was the earliest Canadian children's magazine. ${ }^{10}$ Following Confederation, the Canadian Mlustrated News (1869-1883) was the young nation's first illustrated magazine and. the first in the world to make use of half-tone technology in reproducing illustrations. ${ }^{11}$

In the diffusion of printed materials, 19 th century English-speaking Quebec also displayed verve and energy, with Montreal being the focal point of activity. Of the approximately 165 libraries that emerged in Montreal during the century, around $50 \%$ were anglophone. ${ }^{12}$ The most significant were probably the McGill University Library, the Fraser-Hickson 


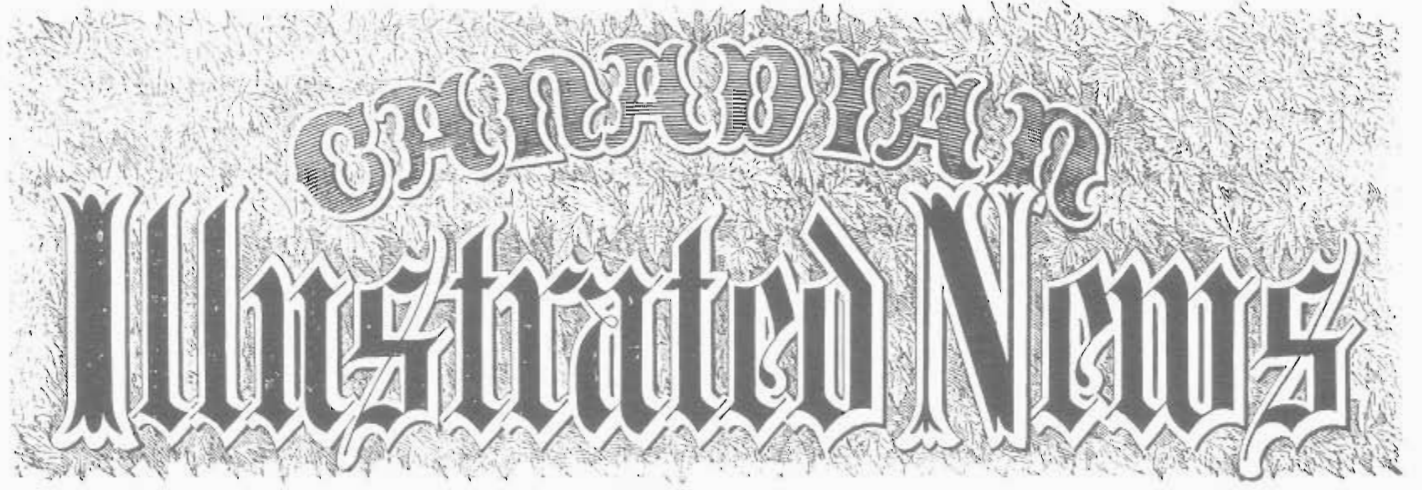

VoL. L. - No. 27.]

MUNTREAL, SATURUAY, MAY 7, 1870.

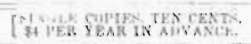

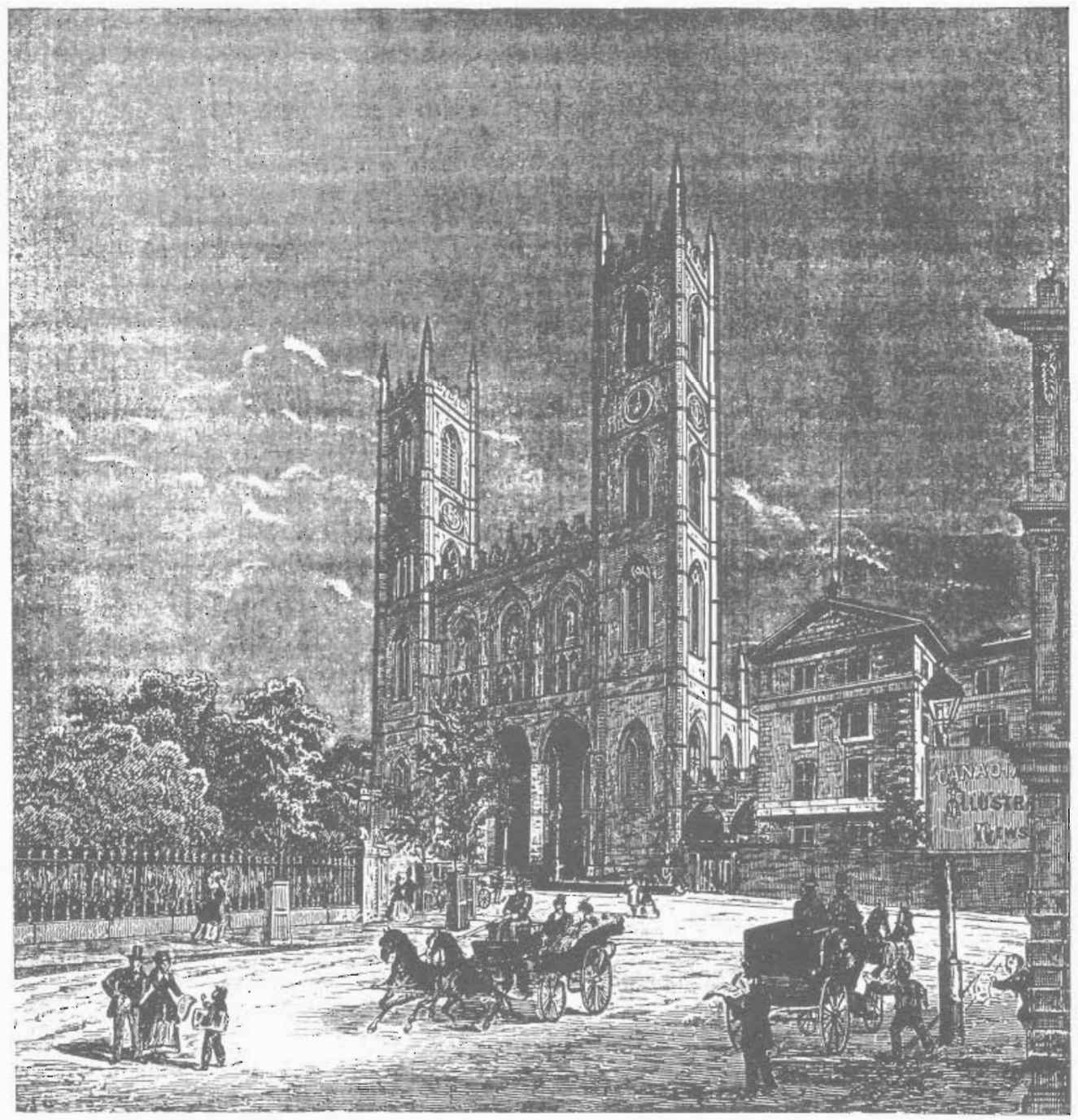

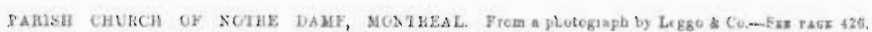


Library and the Mechanics' Institute Library. ${ }^{13}$ Important private collectors emerged during this era, of whom Peter Redpath is probably the most important, with his outstanding collection of 17 th, 18th, and 19th century British Tracts given to McGill University. Although the community was largely insulated from the more extreme aspects of the lay/clerical struggle that tore apart the francophone community during the fight over the library of L'Institut canadien, this struggle would effectively thwart any attempts to found a public library in Montreal until the next century. A. large number of anglophone bookstores developed during the 19th century, but have received little if any study.

\section{1890 to the Present}

In the $1890 \mathrm{~s}$, with the harmonization of copyright laws and protection in Canada, Britain, and the United States, there ended the unauthorized reprinting, without royalties, of books published in the three countries. This coincided with the shift of Canada's English language publishing centre from Montreal to Toronto, where both indigenous local publishers and branch offices of British and American firms established themselves. Although some local anglophone publishers, such as Lovell and Dawson/Renouf, have continued in Montreal from the 19 th century they have concentrated, like most of the English language publishers established during the last one hundred years or so, upon specialized markets rather than national mass markets. Virtually all anglophone publishing over the last century has been concentrated in Montreal. That said, publishing and other aspects of English language print culture in the province continue to maintain themselves despite the shrinking size of the community and the relative economic decline of Montreal.

At the turn of the century, the McGill University Library inaugurated the reprint series, the McGill University Publications, which is an important precursor of academic publishing in this country. ${ }^{14}$ In fact, the series is the direct ancestor of the McGill University Press, established in 1960 and reorganized as the McGill-Queen's press in 1968. Run jointly by McGill and Queen's University, the press is one of the largest and most pres- tigious academic publishers in Canada. Other notable general anglophone publishers were/are Louis Carrier/Mercury (c.1920-1931), Harvest House (1960-), Vehicule (1973-), Eden (1980s), Robert Davids (1992-).

In addition, several specialized presses have developed such as Tundra (children's, 1967) and Black Rose (left wing politics, 1970-). Reference should also be made to the large number of small literary presses appearing in Montreal during and after World War II: First Statement, Contact, Delta Canada, New Delta, Muses's Company, Guernica, and NuAge, to name a few. In fact, for a period during the 1950s and 60s Montreal may well have been English-speaking Canada's literary/poetry publishing capital. Finally it should be noted that newspapers will publish books on occasion, and that a host of minor imprints have risen and fallen over the decades. At the very least, English-speaking Montreal continues to be a significant regional publishing centre with some national impact.

Periodical publishing in English has undergone great change over the past one-hundred years. The McGill University Magazine (1901-1906) and its more famous successor the University Magazine (1907-1920) were amongst the most important Canadian journals of informed opinion and general culture in the first two decades of this century. ${ }^{15}$ From c.1950 to 1979, Weekend Magazine was published by the Montreal Star as a glossy pictorial weekend supplement that appeared in newspapers across the country and was read weekly by millions of Canadians. For some decades after World War II, Time Magazine published a Canadian edition in Montreal. Since 1958, Reader's Digest has been publishing its Canadian editions - English and French - in Montreal. Otherwise the only periodicals published in Montreal that have enjoyed national prominence have been literary titles such as the McGill Fortnightly (1920s), and others issued by the small literary presses mentioned earlier. A publication devoted to the study of print culture in Englishspeaking Quebec is Fontanus, from the Collections of McGill University, 1988-. Newspaper publishing has continued to be a major factor in the anglophone cultural presence. Although the number of dailies has steadily declined during this century, so that only two now remain, the Montreal Gazette 

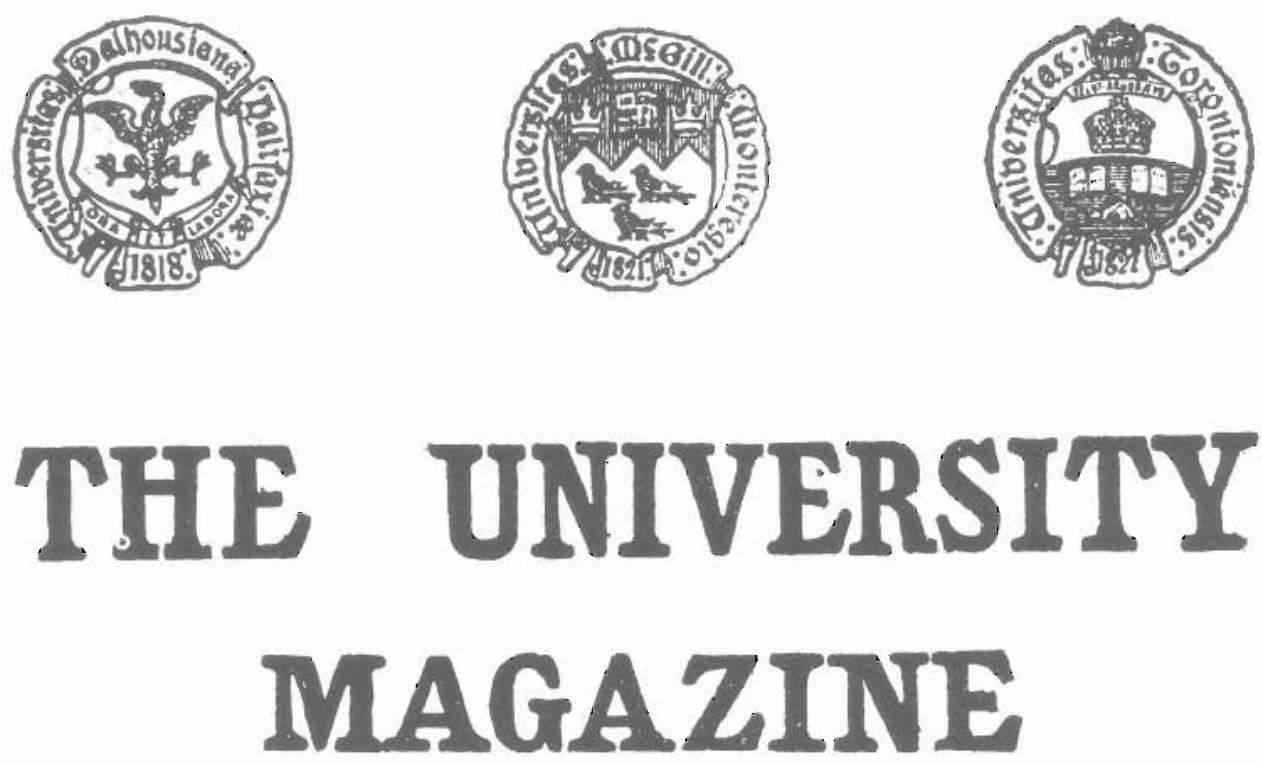

VOLUME VI. 1907

THE MACMILLAN COMPANY

OF CANADA 
and the Sherbrooke Record, many weeklies continue both on the Island of Montreal and elsewhere in the province.

The diffusion of printed material continues to be a central concern of the anglophone community. In 1893 , the province's first specifically designed library building was opened with the inauguration of Redpath Library at McGill University. McGill continues to possess Quebec's largest academic library, with a wealth of research collections - many the gifts of local collectors. Among these research collections are two of particular importance to the study of Canadian print culture: the Canadiana collections and the Colgate Printing Collection. There are a number of other academic libraries at Concordia University and anglophone CEGEPS, or community colleges. The list of Montreal head offices with libraries, which was once sizeable, has shrunk as the city has declined in importance as a financial centre. In 1899, Quebec's first tax-supported public library was opened in the largely English-speaking Montreal suburb of Westmount. ${ }^{16}$ In the early years of this century, McGill operated the Mclennan Travelling Library, which provided books for rural Quebec and the rest of the country until its provincial government grant ceased in 1970. In a province that is only slowly developing a public library system, the anglophone communities are frequently characterized by their libraries. Montreal's Jewish community has developed an excellent library. ${ }^{17}$

In 1904, McGill inaugurated Canada's first formal educational programme for librarianship, which also enjoys the distinction of being the oldest university based programme in the world, outside the United States. ${ }^{18}$ In 1930, it published the first bibliography of Canadian bibliographies. ${ }^{19} \mathrm{~A}$ wide range of English language bookstores can be found in Quebec, mostly in the Montreal region. The Classic Book chain, c.1950-1980, a major force in Canadian retailing, was centered in Montreal. The city has also had outstanding and colourful antiquarian book dealers, of whom Bernard Amtmann was an outstanding example. His Montreal Book Auctions were of national significance through the $1960 \mathrm{~s}$ and $70 \mathrm{~s},{ }^{20}$

As the footnotes will show, this survey has been based upon a relatively narrow research base. That said, many important aspects of Quebec's anglophone print culture still require serious investigation of synthesis: literacy and education, ${ }^{21}$ native peoples, publishers and printers, bookstores and other forms of distribution, censorship, and libraries of all sorts including personal libraries. Attention should also be paid to the print culture of Quebec's ethnic communities, other than English or Frenchspeaking. The real need is, however, for a synthesis of the history of Quebec's anglophone and francophone print culture that respects both their unique and shared qualities.

\section{Notes}

1. D. McTernan, French Quebec: Imprints in French from Quebec, 1764-1990, in the British Library: a Catalogue. London, British Library, 1992$93,2 \mathrm{v}$.

2. F. Waldon, Bibliography of Canadiana Published in Great Britain, 1519-1763. Ottawa, National Library, 1990.

3. E. Waterson, The Travellers: Canada to 1900. an Annotated Bibliography of Works Published in English from 1577. Guelph, University of Guelph, 1989.

4. M. Tremaine, A Bibliography of Canadian Imprints, 1751-1800. Toronto, University of Toronto Press, 1952. M. Vlach, Cataglogue collectif des impressions quebecoises, 1764-1820. Montreal, Bibliotheque nationale du Quebec, 1984.

5. M. Brisebois, The Printing of Handiblls in Quebec City, 1764-1800; a Listing with Critical Introduction. Montreal, Graduate School of Library and Information Studies, McGill University, 1995.

6. P. McNally, "Canadian Library History in English, 1964-1984; a Survey and Evaluation." and "Canadian Library History in French, 1964-1984; a Survey and Evaluation." in Readings in Canadian Library History, ed. by P.F. McNally, Ottawa, Canadian Library Association, 1986. p. 19-39. "Canadian Library Hsitory in English and French to 1964; a Survey and Evaluation." in Readings in Canadian Library History 2, edited by P.F. McNally, Ottawa, Canadian Library Association, 1996. p. 3- 
36.

7. G. Parker, The Beginnings of the Book Trade in Canada. Toronto, University of Toronto Press, 1985. B. Whiteman, Lasting Impressions: a Short History of English Publishing in Quebec. Montreal, Vehicule Press, 1994.

8. G. Baker, Sources in the Law Library of McGill University for a REconstruction of Legal Culture of Quebec, 1760-1890. Montreal Faculty of Law, McGill Unviersity, 1987. J. Connor, "To Advocate, to Diffuse, and to Eelvate: the Culture and Context of Medical Publishing in Canada, 1630 to 1920." Ph.D. Thesis, University of Western Ontario, 1992. C. Roland, An Annotated Bibliography of Canadian Medical Periodicals, 1826-1975. Hamilton, Hannah Institute, 1979.

9. W. Kesterton, A History of Journalism in Canada. Toronto, McClelland, 1967. B. O'Donnell. Printed Sources for the Study of English-Speaking Quebec; an Annotated Bibliography of Works Published before 1980. Lennoxville, Bishop's University, 1985. -Sources for the Study of English-Speaking Quebec; an Annotated Bibliography of Works Published between 1980-1990. Lennoxville, Bishop's University, 1992. C. Cardinal, The History of Quebec: a Bibliography of Works in English. Montreal, Centre for the Study of Anglophone Quebec, Concordia University, 1981.

10. Whiteman, p. 55. M. MacDonald, "Literature and Society in the Canada, 1830-1850" Ph.D. Thesis, Carleton University, 1984.

11. Canada Mlustrated, the Art of NineteenthCentury Engraving. Toronto, Dreadnaught, 1982.

12. Y. Lamonde, "Social Origins of the Public Library in Montreal." Canadian Library Journal, v. 38 , no. 5 (Dec. 1981) p. 363-370.

13. P. McNally, "McGill University Libraries" Encyclopedia of Library and Information Science. New York, Dekker, 1976. v. 27, p. 311-320. E. Moody, The Fraser-Hickson Library, an Informal History. London, Clive-Bingley, 1977. The Mechanics' Institute of Montreal, 1840-1940. Montreal, Institute, 1940 .

14. P. McNally, "Scholar Librarians: Gould, Lomer, and Pennington," Fontanus: from the Col- lections of McGill University, v. 1 (1988) p. 95104; R. Makela, McGill University Library during the Tenure of Charles H. Gould as University Librarian, 1893-1919. Montreal, Graduate School of Library Science, 1974.

15. P. McNally, "Canadian Periodicals and Intellectual History: the Case of the McGill University Magazine/University Magazine, 1901-1920." Bibliographical Society of Canada Papers, v. 19 (1980), p. $69-78$.

16. E. Hanson, "A Jewel in the Park: Westmount Public Library, 1897-1918." Ph.D. Thesis, Indiana University, 1994.

17. S. Gubbay, "The Jewish Public Library of Montreal, 1914-1952." M.A. Thesis, McGill University, 1983.

18. P. McNally, "Fanfares and Celebrations: Anniversaries in Canadian Graduate Education for Library and Information Studies." in Readings in Canadian Library History 2. p. 39-56.

19. M. Higgins, A Bibliography of Canadian Bibliographies. Montreal, McGill University, 1930.

20. J. Mappin and J. Archer, Bernard Amtmann, 1907-1979: A Personal Memoir. Ottawa, Amtmann Circle, 1987.

21. R. Magnuson, A Brief History of Quebec Education: from New France to the Parti-Quebecois. Montreal, Harvest, 1980. 